\title{
Between Retributive and Restorative Compulsory School Teachers' Discipline Activities
}

Katja JeZniK ${ }^{\star 1}$, Robi Kroflič ${ }^{2}$ And MetKa KuHAR ${ }^{3}$

$\approx$ In Slovenia, compulsory schools have, since 2009, been obliged to define their own concept of moral and character education under the formal framework of the Primary School Act. Disciplinary measures in schools are underpinned by two main punishment theories: the more traditional retributive responses to undesired conduct, and the more recent restorative approach. The present study explores the views of 109 teachers from 13 compulsory schools regarding disciplinary measures through the prism of this paradigmatic divide. A qualitative analysis of group discussions in which teachers evaluated the disciplinary measures at each of the 13 schools will be presented. Only three discussion groups were predominantly restorative oriented. Given the proven negative effects of retribution-oriented disciplinary measures, the findings are not encouraging. We conclude that schools need a clearer disciplinary framework with systematic acquisition of knowledge and practical experience in the field of educational and discipline strategies, and that teachers must continuously reflect on their own disciplinary practices.

Keywords: compulsory school, restorative and retributive school measures, education, disciplining

$1 \quad{ }^{*}$ Corresponding Author. Department of Pedagogy and Andragogy, Faculty of Arts, University of Ljubljana, Slovenia; katja.jeznik@ff.uni-lj.si.

2 Department of Pedagogy and Andragogy, Faculty of Arts, University of Ljubljana, Slovenia.

3 Faculty of Social Sciences, University of Ljubljana, Slovenia. 


\section{Med retributivno in restorativno naravnanimi vzgojno- disciplinskimi odzivi učiteljev v osnovni šoli}

Katja JeZnik, Robi Kroflič in Metka Kuhar

$\approx$ Od leta 2009 so osnovne šole v Sloveniji dolžne opredeliti lasten vzgojni koncept, ki ga v formalnem smislu opredeljuje Zakon o OŠ. V ozadju dokumentov, ki jih pripravljajo na šolah, lahko prepoznamo dve glavni teoriji kaznovanja: bolj tradicionalno, tj. retributivno, in novejšo, tj. restorativno. Skozi prizmo paradigmatskih razlik med obema teorijama so v članku predstavljeni izsledki raziskave, v kateri je sodelovalo 109 učiteljev iz 13 osnovnih šol. Predstavljeni so izsledki kvalitativne analize skupinskih razprav na šolah. V razpravah so se učitelji opredeljevali do vzgojno-disciplinskih ukrepov na lastni šoli. Le v treh skupinah so bili učitelji bolj naklonjeni restorativni teoriji kaznovanja kot retributivni. Glede na dokazano negativne učinke retributivno naravnanih disciplinskih ukrepov ugotovitve niso spodbudne. Avtorji vidijo rešitve v sistematičnem izobraževanju učiteljev in teoretsko jasnejši zastavitvi vzgojno-disciplinskih odzivov šol. Hkrati pa bi morali učitelji ves čas reflektirati lastne odzive na vzgojno-disciplinske izzive v šoli.

Ključne besede: osnovna šola, retributivni in restorativni vzgojnodisciplinski ukrepi, vzgoja, discipliniranje 


\section{Introduction}

A compulsory school is a place where different views exist and complex activities are performed by all stakeholders. While the goals of schooling are relatively clear in the subject curriculum, the school's educational ${ }^{4}$ activities are less clear. Subsequent to changes enacted in the school system in the 1990s after Slovenian independence, the educational dimension was supplanted by the schooling dimension due to the threat of repeating the former socialist ideology. ${ }^{5}$ Consequently, education became limited to a narrower, disciplinary view aimed at ensuring an uninterrupted teaching process. Educational activities were legally regulated at the systemic level by the Rules on the Rights and Duties of Pupils in 1996, 1998 and 2004, with clearly set out sanctions for violations. Neither teachers nor other education professionals were satisfied with this solution. Teachers reported reduced autonomy regarding their educational activities, and other professionals warned that education should not be solely focused on how to maintain discipline in the classroom (Šebart \& Krek, 2009).

Since the adoption of the Primary School Act (2007), Slovenian schools within compulsory education (6 to15-year-olds) have maintained a high level of autonomy in determining their educational activities and disciplinary measures. ${ }^{6}$ Since September 2009, each school has followed its own Educational Plan, which defines ways of achieving educational goals and values, taking into account the needs and interests of pupils and the specifics of the wider environment, as well as School Rules. The latter more precisely define pupils' duties and responsibilities, as well as determining rules of conduct and sanctions for violations. Both documents account for pupils' fundamental rights, as defined in the Primary School Act, which are aligned with the rights provided in the Constitution of the Republic of Slovenia and international documents on

4 In this article, the term "schooling" refers to acts or processes of imparting particular knowledge and skills to pupils, such as those required for a profession, while the terms "education" and "educational" refer to processes or actions related to the more holistic development of the personality.

5 The main argumentation of the proponents of the claim that education in schools should be reduced to schooling was that any concept of moral and character education has a specific ideological background, so it is better to focus on instructional aims and the necessary formal discipline regulation based on retributive legal theory. Although the claim about the necessary ideological background of any educational curricula is correct (Kelly, 1989), it is also true that, in the ideological vacuum of postmodernism, teachers become victims of the pressure of many particularistic ideological ideas about proper educational and discipline measures (Štrajn, 1992).

6 In this article, disciplinary measures are considered as activities that accustom pupils to accepting the school rules, including various disciplinary practices. On the other hand, following the Primary School Act (2007), education is understood in a broader sense as proactive and preventive activities, counselling, guidance and other activities (awards, types of educational measures, etc.) with which the school develops a safe and stimulating environment in which the educational values mentioned in the Act (e.g., active inclusion in a democratic society) can be realised. 
children's and human rights. Professionals, pupils and parents are involved in the preparation of both the Educational Plan and the School Rules, which must be reconfirmed every school year by the school council, as these documents are supposed to be continuously evaluated and, if necessary, reformed. The idea of such an arrangement is to promote the systematic, planned, comprehensive and participative regulation of discipline. The only disciplinary measure that is predetermined by the Act and has the status of an administrative procedure is the so-called formal disciplinary procedure. ${ }^{?}$

After the adoption of the Primary School Act, schools received relatively little support by way of expert recommendations and guidelines. During the same period, a document entitled Recommendations for the Preparation and Implementation of a Compulsory School Educational Plan (2008) was published. This document was actually created in parallel with the documents in individual schools. Four years later, The Educational Mission of the School: Planning Manual (Štraser et al., 2012) was issued. Although these manuals reflected the values and principles of educational activity and provided suggestions for concrete educational activities and disciplinary measures for schools, the schools themselves had autonomy in determining an educational theoretical basis. As a study of a sample of 30 principals showed (Šinkovec, 2017), when planning education, schools relied primarily on (personal) experiences (almost all respondents), while only $63 \%$ of the principals stated that their educational plan was based on a particular theory, as well.

Such autonomy for schools can be confusing, since they employ different, and even polarised, guidelines from relevant sources (pedagogy, psychology, various psychotherapeutic approaches, class management theories, etc.). Moreover, the issue of disciplinary measures seems to create a divide in the professional community and, ostensibly, between teachers and other school actors. While some experts call for stricter rules and disciplinary measures and tougher sanctioning of undesired behaviour (e.g., Žorž, 2013), others see the potential of dialogue for resolving conflicts and other educational challenges, possibly based on the systematic development of prosocial, participative relationships between school protagonists (e.g., Čačinovič-Vogrinčič, 2008; Kroflič et al., 2011). The paradigmatic divide can also be perceived in the relationship

7 As an extreme disciplinary measure, a school may impose on a pupil three so-called formal disciplinary warnings per school year; if ineffective, re-schooling can be proposed. Issuing a formal disciplinary warning involves preparing an individual educational plan jointly with the pupil, parents/guardians and teachers concerned. The plan is usually made by the school counselling service, whose chief responsibility is to collaborate with class teachers to resolve complex disciplinary issues and prepare the relevant documents. This measure is also a warning to the parents of the pupil that their child's behaviour is unacceptable and that the school may pursue formal measures to acquire the right to suggest re-schooling the pupil. 
between formal disciplinary procedures and the so-called alternative disciplinary measures suggested by the Recommendations (2008): consultative conversation, restitution and mediation. ${ }^{8}$

In Slovenia, however, there is no comprehensive evaluation of the almost ten-year period of autonomous planning of educational activities, and no systemic insight into the disciplinary views of teachers and other school actors. There are only a few partial analyses focused on the introduction of educational plans (Šinkovec, 2017; Štraser et al., 2012), which indicate that recent educational documents tend not to be implemented in practice.

The present study focuses on the period of autonomous implementation of educational plans by exploring how teachers understand and implement disciplinary measures. Teachers' views are analysed through the prism of the retributive versus restorative duality. The restorative approach today - having been transferred from criminology to the school domain in the early 1990s - is widespread and underpinned by many manuals. Research suggests that it is more effective in delivering the required behavioural change than traditional punitive sanctions. Moreover, compared with such sanctions, it significantly supports the personal development of young people and the school climate, and even leads to better learning outcomes (Thorsborne \& Blood, 2013). At the same time, it has been consistently documented that retributive/punitive school discipline deprives students of educational opportunities and even increases the likelihood of future disciplinary problems (Gonzales, 2012). Furthermore, it has particularly negative consequences for children who are already dealing with multiple sources of stress and trauma in their lives (Thorsborne \& Blood, 2013).

In light of this evidence, the present study seeks to determine the extent to which teachers think and act in a restorative or retributive way. Since no school in Slovenia claims to use the restorative approach systematically, in the qualitative part of the study ${ }^{9}$ the implicit ways in which restorative versus retributive attitudes reveal themselves were researched. The attitudes of 109 teachers from 13 schools were obtained from discussions. The participants evaluated various disciplinary measures in a concrete disciplinary situation (vignette), and they also commented on the vignette in groups, expressed opinions on disciplinary measures in their own school, and gave recommendations for how

8 Schools can impose other disciplinary measures as well, such as sending a notice or making a telephone call to parents, withholding privileges (e.g., participation in a school excursion), etc.

9 Since these discussions were part of a larger research project measuring the quality of communication in professionally facilitated (highly structured) groups vs. usual focus groups, and of the psychological factors determining the quality of discussions, the teachers also completed a (paper-based) survey. The facilitated discussions are not part of the current analysis. 
their school, support institutions and the Slovenian Ministry of Education, Science and Sport could better support them in the disciplinary aspect of their job. The latter is not, however, the focus of this paper.

The next part of the article presents the retributive and restorative educational approaches, substantiating this paradigmatic duality using ethical theories (deontological ethics versus dialogical ethics). Subsequently, we describe the research methodology, present the results and discuss the findings.

\section{Theoretical background}

\section{Deontological ethics and retributive disciplinary measures}

Kant's deontological ethics $(1988,1993)$ and classic theories of moral development (Kohlberg, 1996; Piaget, 2005) regard retributive punishment as the most appropriate disciplinary measure for rule transgressions in school, since "young children are too egocentric to be capable of cognitive and moral reasoning and thus unable to develop ethically until they are older" (Edmiston, 2008, p. 3). Kant (1988) emphasised the categorical imperative as a precondition for morality, suggesting that one must always act in a way that can be considered a principle of the most general law. A moral act (good in ethical terms) thus arises from an awareness of the basic criterion of good (a categorical imperative), while any acts society considers illegal (socially inadmissible) must be punished consistently according to the principle of proportionality of violation and sanction.

Theories of children's moral development claim that the cognitive abilities needed for moral judgement develop gradually (Ma, 2013). Therefore, until they are capable of making deductive moral judgements, children should be submitted to unconditional discipline, and any failure to obey rules should be punished consistently. Such education (disciplining) suppresses a child's egocentric view of the world in early childhood, while explaining the undesired act's inadmissibility strengthens their cognitive ability to understand moral norms. According to this logic, only if a child is submitted to conventional norms, with concurrent suppression of their egocentricity and their tendency towards the pleasure principle, will their autonomous, post-conventional morality subsequently develop.

The retributive theory of sanctioning violations is legitimised by the assumption that an adult autonomously decides to commit a harmful act. Such logic can be used to determine a child's/adolescent's punishment in extreme cases, when an adult indisputably assesses that the child/adolescent was aware of the circumstances and anticipated the consequences (Kroflič et al., 2011). It 
is, however, difficult to assess whether a young perpetrator is in fact able to decide how to act appropriately in a given situation. Nevertheless, the defence of consistent retributive punishment of violations has strengthened since the 1970 alongside criticism of overly indulgent, permissive upbringing and the rise of the ideology of neoliberalism, which declares that people, including children, are capable of making free choices (Salecl, 2010).

However, studies are increasingly showing that retributive measures do not produce the desired educational effect, that is, self-correction and self-regulated behaviour (Christie, Nelson, \& Jolivette, 2004; Sellman, Cremin, McCluskey, \& Sellman, 2014; Thorsborne \& Blood, 2013). Retributive measures rely on the re-education power of negative conditioning and not on learning appropriate behaviour. Furthermore, they do not shed light on the circumstances and response types that led to the deviant behaviour, and they fail to strengthen empathy and prosocial motives that are supposed to arouse a desire to rectify harm. These studies also expose several negative effects of retributive measures, such as labelling and subsequent treatment of individuals as "problematic", which leads to their exclusion.

\section{Dialogical ethics and restorative justice}

Modern dialogical ethics and dialogical educational approaches emphasise the individual's ability to establish respectful and caring relationships as the key to their ethical conduct (Bingham \& Sidorkin, 2004; Kroflič, 2007; Noddings, 1998; Rinaldi, 2006; Rogers, 2014). They place great emphasis on the development of positive personal characteristics or virtues, with empathic prosocial capacities that arise in direct confrontation with other individuals being key; they suggest that the condition of moral conduct is the capacity to empathise with a person, along with a motivational shift from an egocentric perception to caring for that person (Noddings, 1998). A vital role in ensuring morality is played by prosocial emotions, such as empathic guilt (Benjamin, 2000) and compassion (Kristjansson, 2004), while, in a broader sense, the task of moral education and disciplining is to develop these capacities and experience caring relations, which is most easily achieved in an inclusive community that accepts its members' diversity and the need to respect differences (Biesta, 2011).

The basic principle of restorative justice as a disciplinary measure is to seek to restore the situations of all those affected to what they were before the violation, whereby those directly involved should be able to participate fully in finding suitable solutions. This approach enables the victim to present his or her story and particulate actively in the settlement process, while the perpetrator 
is encouraged to transform so as to align his or her expectations with those of the community. This act requires much more significant input from the perpetrator in the settlement process than traditional punishment does, as he or she is supposed to approach the victim with empathy, confess the damage done, and offer compensation by performing agreed acts, resulting in a change in the problematic behaviour. The most typical restorative measure is mediation (Cremin, 2007; Kroflič et al., 2011).

The idea of restorative justice has expanded over the decades from a specific sanctioning logic to a comprehensive educational approach. Effort has been made to design comprehensive school community systems that are not solely focused on restorative justice in the sense of responding to disciplinary issues. The question of how the school can contribute to creating a healthy school environment has been a major consideration. Thorsborne and Blood (2013) emphasised the deliberate development of values, attitudes and skills in teachers and pupils, as well as in school management and families. This broad understanding of restorative education requires the school to consider all aspects of its activities, culture and organisation, and to focus on relational practices that help prevent inappropriate behaviour in the first place (Blood \& Thorsborne, 2005). It is, however, also important to ensure that restorative practices are not exclusive.

\section{Method}

In our research, we examined how teachers assessed the disciplinary measures in their own schools. They evaluated various disciplinary measures in a concrete disciplinary situation (vignette) and commented on the vignette in groups.

\section{Sample}

The 109 participants were teachers working in 13 compulsory schools. The schools were selected according to predetermined criteria in order to ensure that all 12 Slovenian regions were represented, and that the sample included schools of different sizes from larger and smaller cities, suburban areas and rural areas. The sampling method was nonprobability purposive sampling. After identifying the sample, the principals were contacted in order to extend invitations to participate in the study. Three principals declined to participate, so principals from other comparable schools in the same regions were contacted. The principals obtained consent from their teachers, who were informed about 
the topic and format through a one-page document that had been drawn up. In individual schools, teachers of grades six to nine participated voluntarily. Discussions were held at the participating schools in December 2015 and January 2016.

The analysed sample of teachers comprised $78.3 \%$ women, as can be expected given the gender structure of the population of compulsory school teachers, which has recently been found to be $79.4 \%$ female for the second stage of compulsory education (Statistical Office of the Republic of Slovenia, 2016). The ages of the respondents ranged from 26 to 63 years, with an average age of 46.1 (standard deviation $[S D]=9.27$ ). Participants with less than 10 years teaching experience made up $19.1 \%(\mathrm{~N}=43)$ of the sample, those with $10-20$ and $20-30$ years of teaching experience accounted for $29.5 \%(\mathrm{~N}=67)$ and $28.7 \%(\mathrm{~N}$ $=65)$, respectively, while $22.6 \%(\mathrm{~N}=51)$ of the participants had been teaching for over 30 years. The teachers were working at schools with student populations ranging from 230 to 837 pupils.

\section{Data collection and analysis}

The teachers in each school were randomly divided into groups of 8-10 members. Each group followed two guidelines: the teachers could not change the topic and must not be overtly disrespectful. A member of the research group attended the discussions and posed substantive questions without directing the discussion. Each discussion lasted about 1.5 hours.

Before the discussion, the teachers read a vignette description of the following practical problem: ${ }^{10}$

Three boys from the seventh grade left the school building. Martin and Luka rode their bicycles. Luka pushed Martin off his bicycle while he was riding it in the school yard. Martin fell off the bicycle and became angry; he grabbed the chain lock, started swinging it around his head and ran after Luka. Tim also started to chase Luka. He caught him and held him so that Martin could reach him with his chain. When Martin approached, he hit Luka with the chain, but Luka managed to break away and run off. A teacher observed the whole scene from a window.

The teachers first discussed the response strategies in the presented

10 The description was selected from notes made by students of the Department of Educational Sciences of the Faculty of Arts in Ljubljana, which are prepared every year during study practice within the course Planning of the Public School Educational Concept. 
situation and then evaluated the disciplinary measures in their own schools.

In addition to the person leading the discussions in substantive terms, every group included another person documenting the discussion (recording, ongoing note-taking and noting of statements). For the analysis, we structured the notes and determined the coding units whose common notions were identified following the presented theoretical premises (Vogrinc, 2008). The definition of codes for the discussion analysis was grounded in theory and was verified by the collected statements. As retributive voices, we identified teachers' statements that focused on keeping track of previously anticipated and specific responses to the situation. As restorative voices, we defined those comments linking educational activities to mediation, restitution and conversation (which, according to theory, are typical restorative measures) and comments reflecting a clear desire for dialogue and consideration of the context of the situation. This represented a "deductive coding" process (Flick, 2006), or so-called closed coding.

The study results were presented to the participating teachers during a special symposium held in September 2016. Forty teachers from the participating schools attended. Thus, the findings were consensually validated (Telban, 2014), but cannot be generalised.

\section{Results}

\section{Teachers' comments on the vignette}

Although the vignette described a serious violation (violent behaviour), which the School Rules state could entail the formal sanction of a formal disciplinary warning, none of the teachers chose such unequivocal argumentation in any of the discussions. However, all 13 groups evaluated the vignette case as a serious violation due to the possibility of serious injury.

Teachers from all of the schools agreed that immediate action was required, although in six of the groups there were teachers who expressed the opinion that any intervention should be avoided (especially at the start of the conversation, when they spoke in the third person) and questioned the scope of their necessary (legal) responsibility or expressed insecurity about the limits of acceptable intervention. Below are some responses showing a feeling of powerlessness, which can lead to a cynical position.

If it isn't in school or during class, it's better not to react, because taking action is too demanding in formal terms and otherwise. $\left(\mathrm{S}^{11} 4\right)$

You separate them immediately. But we can't do this because we aren't 
allowed to touch them physically and we are afraid of the consequences. (S 8)

In groups where such concerns arose, participants argued that the moral (ethical) responsibility is as important as the legal responsibility (in terms of respecting the strict letter of the law). All of the groups agreed on the necessity of notifying the parents and possibly having a conversation with the pupils. They agreed that the class teacher, principal and school counsellor should, in principle, be informed of the violation.

The prevailing opinion in most of the groups was that, if the teacher does not feel sufficiently competent, the case should be taken over by a school counsellor. Teachers in some groups even agreed that the police should be called.

It would be the easiest if they [the police] resolved this. (S 10)

In the discussion groups, both retributive and restorative voices were present, and teachers confronted each other more or less dialogically. Although the survey results did not reveal any statistically significant differences between schools in the restorative index (Kuhar \& Jeznik, 2017), the discussions did indicate certain differences. Three of the groups were completely or largely inclined towards a restorative approach. Below is an example of an extensive response that was given in one of these groups. The following statement was made by a participating teacher, while the others in the group agreed non-verbally (e.g., by nodding) and later complemented what was said.

Taking measures is necessary in order to interrupt the violence and clearly indicate to everyone involved that it shouldn't be done this way. When the children calm down, it's necessary to have a conversation with them to make them aware of the causes, consequences, etc. Teachers who are qualified mediators would carry out the mediation process the next day and establish how every person perceived the event, how they experienced it, what happened before, why such a heated reaction occurred, what the background was, etc., as well as how to resolve the situation, make resolutions for the future, etc. They would also define a more appropriate reaction! If a teacher doesn't feel competent for mediation, this can be done by the school counsellor. It's certainly reasonable to inform the counsellor about the event. Parents must be included in one way or another. Then there must be a consequence - it depends on the people involved and the situation - sometimes restitution is reasonable, but not necessarily. Formal 
disciplinary warnings are very rare in our school. Last year, there was only one, and this was above average. If there is a formal measure - but only when justified - it should be imposed only after the situation has been completely cleared up. Then more attention should be paid to the pupils, and [there should be] a class meeting dedicated to the topic of measures imposed when something goes wrong. ( $\left.\mathrm{S}_{12}\right)$

The statement below came closest to retributive logic, reflecting a desire to react according to the school rules with regard to serious violations.

It should be acted upon as stipulated in the rules. Serious violations, like this one, require a formal disciplinary warning. $\left(\mathrm{S}_{7}\right)$

This measure was further substantiated by referring to its value for the community:

A disciplinary measure is a message for the whole school. ( $\left.\mathrm{S}_{7}\right)$

At the same time, in those discussions where the necessity and reasonableness of a disciplinary measure were emphasised, (other or the same) teachers noted additional aspects of disciplinary measures leading to restorativeness:

A measure alone isn't enough; a conversation is also needed. ( $\mathrm{S} 11)$

Like this: individual conversations with all those involved, their confrontation, punishment and apologies. And informing the parents. (S 2)

In a discussion on the need for sanctioning, teachers in some of the schools emphasised that the measure taken depends on previous actions:

The measure is adjusted to the pupil; it depends on how often they have already broken the rules. $\left(\mathrm{S}_{1}\right)$

\section{Teachers' attitudes towards existing disciplinary measures}

In part two of the discussions, the teachers stated which violations they or their school encountered most frequently. In most of the schools, interrupting class, telephone use outside the permitted area and peer violence (including online) were listed. The greatest differences between schools were seen in the frequency of what was considered a violation. 
In the second part of the discussion, the teachers expressed their views on their school's disciplinary measures. As in the vignette part of the discussion, the groups differed in terms of their inclination towards the restorative or retributive paradigm; opinions varied substantially among the discussion participants. In three of the schools, however, the teachers' opinions in favour of restorative practices were consistent across the group.

\section{Formal disciplinary warnings}

Teachers from all of the schools expressed dissatisfaction with the formal disciplinary procedure. They highlighted many procedural deficiencies, especially bureaucratisation, which requires teachers to be well versed in administrative procedures. Moreover, they expressed a fear of parents making legal complaints about the measure.

The measure-imposing procedure is bureaucratically very complex. I prefer not to impose one because I refuse to complete all those forms and write explanations. ( $\mathrm{S}_{2}$ )

Imposing formal disciplinary warnings is legally too complicated because everything is defined so precisely. Parents can quickly challenge it due to a failure to consider all the details. It's too bureaucratic, as well. (S 10)

\section{Conversation}

Teachers discussed so-called alternative measures: consultative conversation, mediation and restitution. The statements revealed that many teachers were aware of the importance of the long-term effects of a conversation compared to the short-term effect of retributive punishment.

A conversation is not enough. However, violations must be highlighted through conversation, not punishment. Otherwise, children are unaware of the consequences and what their reasons were. $\left(\mathrm{S}_{5}\right)$

A punishment, deprivation of something, blaming, etc. doesn't solve anything and worsens the situation because children withdraw and cooperate even less. We want the child to know they are accepted, heard, seen... that they can express their tension. We allow them to feel it and not suppress it in their subconscious mind, to let it out; yet we want to teach them different, more acceptable behaviour. We want them to know that they are okay, but that certain actions are not okay. (S 6) 


\section{Mediation}

Nearly all of the participating schools have mediation in their Educational Plans and School Rules, but in practice it is developed to different degrees. Certain teachers expressed satisfaction with mediation, while others doubted its reasonableness and effectiveness.

It would be reasonable to develop a peer mediation system (e.g., a small circle of mediators) and spread the mediation spirit among pupils in the sense of quality conflict resolution and good relations generally. (S 10)

Mediation with a teacher yields good results. (S 9)

We don't implement mediation, although we have 12 teachers who are qualified as mediators. Children only give the desired answers. You need two mature individuals for mediation, who are really willing to resolve the dispute. It must be spontaneous, not a formal procedure. (S 11)

\section{Restitution}

Formally, restitution was an optional measure in all of the participating schools. In many statements, teachers revealed a lack of understanding of this measure; thus, it is no coincidence that restitution was not classified as a restorative index measure in the survey (Kuhar \& Jeznik, 2017). The following statements highlight the teachers' active role in proposing restitution to a pupil rather than the perpetrator's active role, raising awareness and agreeing on what would constitute a "good deed".

Restitution is unreasonable because if someone carries out a good deed, they need a supervisor or somebody else to work with. And the work must be such that they really dislike it. ( $\left.\mathrm{S}_{3}\right)$

We are satisfied with restitution, but it's annoying that the measure is chosen by the class teacher and not the teacher involved. ( $\left.\mathrm{S}_{10}\right)$

\section{Prevention}

The importance of prevention was emphasised repeatedly in the discussions, such as the development of emotional and social skills in certain pupils or in "problematic" classes (not in workshops, but more promptly and continuously), while the need to encourage conscious effort in building quality interpersonal relations was also highlighted in some groups. 
We organised workshops and worked with psychologists when the problems initially arose; we set up solid foundations and there are no problems now. ( $\mathrm{S}_{5}$, note: a class teacher talking about one class)

Education is as-it-happens in all subjects. It is not reasonable to plan a few hours for this beforehand and then "act smart" for 45 minutes. But there are not enough class hours and not enough space in curricula. There are too many topics to teach, and it's difficult to take more than five minutes here and then resolve a specific situation; however, this is important for life, as a single statement can leave a strong mark on one's entire life. (S 12)

\section{Nostalgia for stricter disciplining}

In some discussions, a feeling of nostalgia arose with regard to the "former" system, in which teachers perceived that they had more disciplinary levers. The desire for more palpable punishments was expressed relatively frequently.

I'd like to see the old times return, and the punishment. (PS 5; note: only 1 of 11 participants in this group expressed this desire)

\section{Perception of parents}

In all of the groups, the educational role of parents was a thoroughly discussed topic. The teachers often viewed inappropriate upbringing at home as the reason for disciplinary difficulties with some children, while some of the teachers also reproached parents for inappropriate interference in their pedagogical work. In some groups, the teachers talked about parents in an empathic way, trying to understand their fast pace of life and their requirements, and stressing the need to establish quality contact with them.

Parents intervene too often, especially 'VIP' parents, who refuse to accept there's something wrong with their child. $\left(\mathrm{S}_{3}\right)$

When cooperating with parents, it's important how the child's violation is presented to them, how contact is established with them to agree on a specific measure, etc. The focus must be on communication with parents, which isn't easy with problematic children - that is, children from particularly problematic families. (S 10) 


\section{Behaviourally difficult students}

Almost all of the groups particularly highlighted so-called behaviourally difficult students:

Approximately $10 \%$ of children are nowadays, and were in the past, behaviourally difficult. The reason is usually in the family. From the end of their first year, children are in institutions, their parents aren't raising them, they just feed them and then sit them in front of the television ... ( $\left.\mathrm{S}_{3}\right)$

\section{Discussion and conclusions}

We began this paper by discussing the current organisation of compulsory education in Slovenia. The transformation from the legalistic understanding of education ten years ago to the present arrangement, which gives schools and teachers significant autonomy in their educational activities but inadequate professional support, has in some ways deepened the fundamental paradigmatic divide between teachers. In the present paper, this divide is conceptualised through the prism of penological theory. We focused on restorative vs. retributive approaches, both as a theoretical framework and as the basis for our empirical analysis. By focusing on the viewpoints of teachers regarding disciplinary measures, we have made at least a small contribution to the insight into what is happening in this important field of teachers' pedagogical work.

An analysis of the teachers' discussions showed that the restorative logic prevailed in three of the participating schools, while restorative and retributive voices coexisted in the others. In the schools where the restorative logic prevailed, this manner of thinking and responding had been systematically developed over a long period, as the teachers themselves reported.

Special attention should be paid to teachers' attitudes towards the most formalised disciplinary measures, that is, formal disciplinary warnings and measures emphasised in the Recommendations (2008), including consultative conversation, mediation and restitution.

Regarding formal disciplinary warnings, the data highlighted the teachers' fear that parents would oppose any disciplinary measure by threatening to lodge a formal complaint with the school inspector or even the court, which is permitted under the formal administrative procedure for imposing disciplinary measures. There are no statistics showing how often such threats are actually carried out. The reason the majority of teachers disapproved of this formal measure is also important: they wanted to avoid the administrative obligation of preparing the documentation required to impose a formal disciplinary 
warning. The teachers also assessed this measure as lacking gradualness.

Consultative conversation was a very frequently highlighted measure. However, conversation as such is not necessarily a restorative measure; it is also used as part of the retributive sanctioning of violations, to clarify the situation and to justify arguments about the inadmissibility of a disciplinary violation that must follow both legal norms and ethical arguments (why a certain act is unacceptable).

Not all of the schools implement mediation. In the schools where mediation had been implemented, the teachers had differing attitudes towards it, more frequently negative than positive. The bulk of the teachers' statements showed a deficient understanding of the potential successful use of mediation with school pupils, while the consideration of pupils' "maturity" for the process indicated that the traditional view of the egocentric orientation of pupils is deep rooted. Of course, (consultative) conversation and mediation are complex processes that should encompass the capacity to empathise with another person (Noddings, 1998), active listening (Rinaldi, 2006), dialogicality (Bingham \& Sidorkin, 2004) and seeking reasonable arguments for all involved (Gibbs, 2003). It would be ideal if teachers, not only school counsellors and teacher mediators, were also appropriately qualified for all of these dimensions.

Theoretically, restitution is a restorative sanction measure. Based on the results, this can be explained by the teachers' lack of understanding of restitution as a method of actively involving the perpetrator in remedying the consequences of the committed act and in the choice of the restorative act. Statements that the teacher should determine a reasonably good deed (e.g., during class) together with the pupil were rare.

The results show that three of the participating schools adopt a restorative approach, even though they do not explicitly use this concept. The attitudes and disciplinary conduct of the teachers at these schools are the result of intentional training. However, the results lead to the conclusion that, in most of the participating schools, teachers lack a thorough understanding of disciplinary measures that are supposed to be restorative (mediation and restitution). In the discussions, retributive voices were nevertheless often overruled by restorative voices. The participants' expressed a desire to have more time for various educational activities aimed at cultivating pupils' emotional and social development (in class hours, voluntary work, even as new subjects). It would appear reasonable to conclude that there is a need to systematically introduce a comprehensive restorative framework, both at the theoretical level and through practical programmes. Besides restorative education, there are several established comprehensive educational frameworks, such as the whole school 
approach (Weare, 2013), positive education (Seligman et al., 2009) and social emotional learning (Zins, Weissberg, Wang, \& Walberg, 2004). As shown in other countries, such practices require transforming the entire school.

Embedding restorative practice needed to be thought of as a vehicle for cultural change. It was clear that a school could not be restorative without substantial re-engineering of the way they did things, behaviour management and at a relational level. (Thorsborne \& Blood, 2013, p. 30)

This does not just concern the school; it would be reasonable to introduce such knowledge and skills in teachers' education, as well. What is needed is process-based education with systematic reflection on acquired knowledge (Štirn Janota, 2016). Currently, the content of teacher education is dominated by market-oriented programmes designed by private providers (Kroflič, 2014).

\section{Acknowledgment}

This work was supported by the Slovenian Research Agency under Grant No. L5-5547.

\section{References}

Benjamin, J. (200o). The Oedipal riddle. In P. U. Gay, J. Evans, \& P. Redman (Eds.), Identity: A Reader (pp. 231-247). Sage.

Biesta, G. (2011). Learning democracy in school and society: Education, lifelong learning, and the politics of citizenship. Sense Publishers.

Bingham, C., \& Sidorkin, A. (2004). No education without relation. Peter Lang.

Blood, P., \& Thorsborne, M. (2005). The challenge of cultural change: Embedding restorative practices in school. Paper presented at The Sixth International Conference on Conferencing, Circles and other Restorative Practices: "Building a Global Alliance for Restorative Practices and Family Empowerment”. Sydney, Australia. http://www.thorsborne.com.au/conference_papers/Challenge_of_ Culture_Change.pdf

Čačinovič-Vogrinčič, G. (2008). Soustvarjanje v šoli: učenje kot pogovor [Co-creation in school: Learning as a conversation]. Zavod RS za šolstvo.

Christie, C. A., Nelson, C. M., \& Jolivette, K. (2004). School characteristics related to the use of suspension. Education and Treatment of Children 27(4), 509-526.

Cremin, H. (2007). Peer mediation: Citizenship and social inclusion revisited. Open University Press Baruch.

Edmiston, B. (2008). Forming ethical identities in early childhood play. Routledge. 
Flick, U. (2006). An introduction to qualitative research. Sage.

Gibbs, J. C. (2003). Moral development and reality: Beyond the theories of Kohlberg and Hoffman. Sage Publications.

González, T. (2012). Keeping kids in schools: Restorative justice, punitive discipline, and the school to prison pipeline. Journal of Law \& Education 41(2), 281-335.

Kant, I. (1988). O pedagogiki [About pedagogy]. Problemi: revija za kulturo in družbena vprašanja, 26(11), 147-158.

Kant, I. (1993). Kritika praktičnega uma [A critique of the practical mind]. Društvo za teoretsko psihoanalizo.

Kelly, A. V. (1989). The curriculum - Theory and practice. Paul Chapman Publishing.

Kohlberg, L. (1996). Die Psychologie der Moralentwicklung [The psychology of moral development].

Suhrkamp.

Kristjansson, K. (2004). Empathy, sympathy, justice and the child. Journal of Moral Education, 33(3), 291-305.

Kroflič, R. (2007). Vzgoja za odgovornost onkraj razsvetljenske paradigme: od razvoja odgovorazmožnosti k spoštljivemu odnosu in razvoju etične zavesti [Education for responsibility beyond the enlightenment paradigm: From the development of responding ability to a respectful attitude and the development of ethical consciousness]. Sodobna pedagogika 58(24), 56-71.

Kroflič R., Klarič T., Štirn Janota P., Stolnik K., Gibbs J. C., Skiba R., et al. (2011). Kazen v šoli? Izbrani teoretski pristopi $k$ sankcioniranju prekrškov in podpori prosocialnega ter moralnega ravnanja. [Punishment in school? Selected theoretical approaches to sanctioning violations and supporting prosocial and moral conduct]. Center RS za poklicno izobraževanje.

Kroflič, R. (2014). Katerim uporabnim interesom služijo bolonjska prenova visokošolskega študija in njeni spremljevalni pojavi [What are the pragmatic interests of the Bologna reform of higher education and its accompanying phenomena?]. Vzgoja in izobraževanje: revija za teoretična in praktična vprašanja vzgojno izobraževalnega dela, 45(3), 10-14.

Kuhar, M., \& Jeznik, K. (2017). Deliberativno razpravljanje učiteljev o vzgojnih ukrepih v osnovnišoli [The Effect of deliberative discussion methods on primary school teachers' attitudes towards educational measures]. Sodobna pedagogika, 68(1), 32-50.

Ma, H. K. (2013). The moral development of the child: An integrated model. Frontiers in Public Health, (1), 57. http://doi.org/10.3389/fpubh.2013.00057

Noddings, N. (1998). Caring: A feminine approach to ethics and moral education. University of California Press.

Piaget, J. (2005). The psychology of intelligence. Routledge.

Recommendations (Priporočila o načinih oblikovanja in uresničevanja vzgojnega načrta osnovne šole) [Recommendations for the preparation and implementation of a compulsory school educational plan] (2008). Educa: strokovna revija za področje varstva, vzgoje in izobraževanja predšolskih otrok in otrok na razredni stopnji osnovne šole, 17(5/6), 71-91.

Rinaldi, C. (2006). In dialogue with Reggio Emilia: Listening, researching and learning. Routledge. 
Rogers, C. R., Lyon, H. C., \& Tausch, R. (2014). On becoming an effective teacher. Routledge.

Salecl, R. (2010). Choice. Profile Books.

Seligman, M. E. P., Ernst, R. M., Gillham, J., Reivich, K., \& Linkins, M. (2009). Positive education:

Positive psychology and classroom interventions. Oxford Review of Education, 35(3), 293-311.

http://dx.doi.org/10.1080/03054980902934563

Sellman, E., Cremin, H., \& McCluskey, G. (2014). Restorative approaches to conflict in schools:

Interdisciplinary perspectives on whole school approaches to managing relationships. Routledge.

Šebart, M., \& Krek, J. (2009). Vzgojna zasnova javne šole [The educational concept of public school].

Center za študij edukacijskih strategij, Pedagoška fakulteta.

Šinkovec, S. (2017). Vzgojni načrt v šoli: spodbujanje celostnega razvoja osebnosti učencev. [The

educational plan at school: Promoting the overall development of pupils' personalities]. Jutro: Inštitut Franca Pedička.

Štirn Janota, P. (2016). Kindergarten teachers notice what they first understand: The importance of process education for kindergarten teachers. Sodobna pedagogika, 67(4), 128-147.

Štrajn D. (1992). Učitelj in njegova resnica Kaj hočemo in kaj zmoremo [The teacher and his truth. What we want and what we can]. In Zbornik s posveta o problemih in perspektivah izobraževanja učiteljev (pp. 60-62). Pedagoška fakulteta v Ljubljani.

Štraser, N., Kramer, M., Margan, U., Bevc, V., Preskar, S., Bizjak, C. et al. (2012). Vzgojno poslanstvo šole: priročnik za načrtovanje [The educational mission of the school: Planning manual]. Zavod RS za šolstvo.

Telban, B. (2014). Metode raziskovanja, argumentiranja in pisanja v humanistiki in družboslovju [Methods of research, arguing and writing in the humanities and social sciences]. ZRC SAZU. Thorsborne, M., \& Blood, P. (2013). Implementing restorative practice in schools: a practical guide to transforming school communities. J. Kingsley.

Vogrinc, J. (2008). Kvalitativno raziskovanje na pedagoškem področju [Qualitative research in the pedagogical area]. Pedagoška fakulteta.

Weare, K. (2013). Promoting mental, emotional, and social health: A whole school approach. Routledge. Zakon o OŠ [Primary school act]. (2007). Uradni list RS, 2007/8, No. 102/2007.

Zins, J. E., Weissberg, R. P., Wang, M. C., \& Walberg, H. J. (2004). Building academic success on social and emotional learning: What does the research say? Teachers College Press.

Žorž, B. (2013). Razvajenost: rak sodobne vzgoje [Being spoilt: The cancer of modern education].

Celjska Mohorjeva družba. 


\section{Biographical note}

KATJA JEZniK, $\mathrm{PhD}$, is assistant professor at the University of Ljubljana, Department of Pedagogy and Andragogy, Faculty of Arts, Slovenia. She is instructor for different courses: Theory of Education, Planning of Moral Education and Discipline Practices in Public Schools and Pedagogical Work with Learners with Special Needs. Her main research areas are identity development, youth changes, vocational education, children with special needs, theory of education, and others.

Metka Kuhar, $\mathrm{PhD}$, is a full professor of Social Psychology at the University of Ljubljana, Faculty of Social Sciences, Slovenia. Her main research interests are in the fields of psychology of communication, mental health and youth studies.

Robi KROFLIČ, $\mathrm{PhD}$, is a full professor of theory of education and general pedagogy at the Department of Pedagogy and Andragogy, Faculty of Arts, University of Ljubljana, Slovenia. His basic fields of investigation are: theory of authority and pedagogical Eros, theories of prosocial and moral education, inclusive education, discipline strategies and punishment, and aesthetic experience as one of the main factors of education. In last years he formed a comprehensive inductive concept of prosocial and moral development. He is especially focused on conditions for a stronger participation and emancipation of children from the vulnerable social groups, and possibilities of prosocial and moral education through artistic activities. 